\title{
Anatomic variability of the thoracic duct in pediatric patients with complex congenital heart disease
}

\author{
Ji Hyun Bang, MD, Sang Hwa Kim, MS, Chun Soo Park, MD, Jeong-Jun Park, MD, and Tae-Jin Yun, MD, PhD
}

\begin{abstract}
Objective: Thoracic duct mass ligation (TDML) through a right thoracotomy (RT), regardless of the side of the pleural effusion, is a standard procedure for chylothorax that is refractory to medical treatment. This procedure may be unsuccessful in patients with complex congenital heart disease, which necessitates additional left thoracotomy (LT) for left periaortic mass ligation. We hypothesized that failure of the right-sided approach is attributable to the anatomic variation of the path of the thoracic duct.
\end{abstract}

Methods: Of the children who underwent surgery for congenital heart disease between 1992 and 2014, a total of 70 of $8880(0.8 \%)$ underwent TDML by RT $(\mathrm{n}=57)$ or LT ( $\mathrm{n}=13$; LT after RT in 10 , and primary LT in 3$)$.

Results: Persistent chylothorax was successfully resolved in 65 patients (65 of 70; 93\%) within 15 days (2-79 days) after the first or second TDML; 5 patients died with a chest-tube(s) in situ. After excluding mortality without chest-tube removal, we sought to identify the risk factor(s) necessitating LT in 65 patients (RT group: 54; LT group: 11). On logistic regression analysis, the LT group was more likely to have dextrocardia (odds ratio: 6.38; 95\% confidence interval: 1.09-37.25; $P=.04)$. The incidence of abnormal atrial situs, great arterial malposition, right descending thoracic aorta, and bilateral superior vena cavae were comparable in the 2 groups.

Conclusions: The path of the thoracic duct may vary in pediatric patients with complex congenital heart disease. Left periaortic mass ligation should be considered in patients with chylothoraces that persist after the right-sided approach, especially in patients with dextrocardia. (J Thorac Cardiovasc Surg 2015;150:490-6)

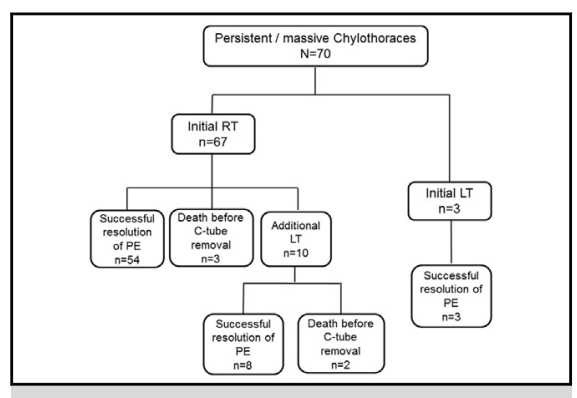

Outcome of thoracic duct mass ligation for postoperative chylothoraces in 70 patients.

\section{Central Message}

If right-sided thoracic duct mass ligation for chylothorax fails in patients with congenital heart defects, especially dextrocardia, a leftsided approach should be considered.

\section{Perspective}

Thoracic duct mass ligation through a right thoracotomy is standard procedure for chylothorax that is refractory to medical treatment. However, this procedure is frequently unsuccessful in patients who have complex congenital heart disease, possibly because of the anatomic variation of the thoracic duct pathway. Left periaortic mass ligation should be considered in this setting.

See Editorial Commentary page 497.
Chylous pleural effusion after pediatric cardiac surgery is a life-threatening complication that leads to long hospital stays and sometimes death. ${ }^{1,2}$ Recent studies have reported that the incidence of chylothorax after pediatric cardiac surgery ranges from $0.89 \%$ to $6.6 \% .^{1-6}$ Conservative measures, including enteral nutrition enriched with medium-chain triglycerides, total parenteral nutrition, and pharmacologic therapy to restrict mesenteric blood supply, ${ }^{5}$ are generally considered for initial treatment. 4,6

From the Division of Pediatric Cardiac Surgery, Asan Medical Center, University of Ulsan College of Medicine, Seoul, Republic of Korea.

Read at the 95th Annual Meeting of The American Association for Thoracic Surgery, Seattle, Washington, April 25-29, 2015.

Received for publication April 21, 2015; revisions received June 15, 2015; accepted for publication June 21, 2015; available ahead of print Aug 5, 2015.

Address for reprints: Tae-Jin Yun, MD, PhD, Division of Pediatric Cardiac Surgery, Asan Medical Center, University of Ulsan College of Medicine, 88, Olympic-ro 43-gil, Songpa-gu, Seoul 138-736, Republic of Korea (E-mail: tjyun@amc.seoul.kr). $0022-5223 / \$ 36.00$

Copyright (C) 2015 by The American Association for Thoracic Surgery http://dx.doi.org/10.1016/j.jtcvs.2015.06.078
If conservative treatment fails, surgical intervention is needed. Among the various surgical methods for persistent chylothorax, $^{7-9}$ thoracic duct mass ligation (TDML) via right thoracotomy (RT), ie, right periaortic tissue mass ligation, is regarded as the standard procedure for prolonged and massive chylous effusion. 6,10-12 However, information regarding the postoperative outcome after TDML in pediatric patients is limited. The rationale for RT in TDML is based on the usual anatomic path of the thoracic duct, which traverses the diaphragm through the aortic hiatus, through the aortic hiatus along the right side of the descending thoracic aorta. Therefore, the success of the right-sided approach depends on the right periaortic path of the thoracic duct being at the level of the diaphragm.

Given that complex congenital heart defects are frequently associated with variations in the path of the thoracic duct, ${ }^{13-16}$ the right-sided approach for TDML may not be successful in patients who have a thoracic duct with a reversed or bilateral path. We hypothesized 


\section{Abbreviations and Acronyms \\ LT = left thoracotomy \\ $\mathrm{RT}=$ right thoracotomy \\ $\mathrm{TDML}=$ thoracic duct mass ligation}

that failure of the right-sided approach may be attributable to anatomic variations of the thoracic duct. We sought to determine the risk factors that require the left-sided approach for TDML.

\section{METHODS \\ Study Populations}

Between January 1992 and July 2014, a total of 298 of 8880 (3.3\%) children who underwent cardiac surgery for congenital heart disease at our institution were diagnosed as having chylothorax. Among these patients, 70 of $8880(0.8 \%)$ with persistent and massive chylothoraces underwent TDML. Standard right periaortic tissue mass ligation through a RT was performed in most of these patients $(n=67)$; the primary leftsided approach through a left thoracotomy (LT) was used in 3 patients who had massive left-sided chylothorax. The decision to perform TDML primarily by LT, rather than RT, was made at the discretion of the attending surgeons. Among the 67 patients who underwent RT, additional LT for left periaortic tissue mass ligation was performed in 10 patients who had persistent ( $>7$ days) and extensive $(50 \mathrm{~mL} / \mathrm{kg} /$ day) pleural effusion. Therefore, a standard right-side approach was used for $57 \mathrm{pa}-$ tients, and a primary or secondary left-side approach was used for 13 patients. Demographic data, cardiac morphology, characteristics of chylous drainage, and postoperative outcomes were compared between the 2 groups. This study was approved by our institutional review board (No. S2015-0500), and the need for informed consent was waived because the study is retrospective.

\section{Thoracic Duct Mass Ligation}

Laboratory diagnosis of chylothorax was confirmed at the median interval of 9 days (range: 2-110 days) after the initial operation, when the triglyceride level in the pleural fluid exceeded $110 \mathrm{mg} / \mathrm{dl} .{ }^{17}$ Chylothoraces were initially managed using various conservative measures, including total parenteral nutrition, enteral nutrition enriched with medium-chain triglycerides, and octreotide therapy. Determination of the duration and types of conservative management before TDML was based on the amount and the side of pleural drainage, comorbidities (eg, capillary leakage syndrome, hepatic and renal dysfunction), and more importantly, individual surgeon preference.

Thoracic duct mass ligation was indicated for prolonged ( $>2$ weeks) or excessive pleural effusion ( $>50 \mathrm{~mL} / \mathrm{kg} /$ day) despite conservative management. For TDML via RT, mass ligation of all the tissue between the aorta and the azygos vein, at the level of the diaphragm, was carried out through posterolateral RT via the sixth or seventh intercostal space. For TDML via LT, the posterolateral LT was carried out through the 6th or 7th intercostal space.

The inferior pulmonary ligament was divided, and the left lung was retracted superiorly. Mass ligation of the left half $\left(180^{\circ}\right)$ of the periaortic tissue at the level of the diaphragm was performed; extreme caution was used to protect the phrenic and vagus nerves. Seventeen patients (17 of 65; $26.1 \%)$ underwent either chemical $(n=3)$ or mechanical $(n=9)$, or both chemical and mechanical $(\mathrm{n}=5)$, pleurodesis upon TDML. No intergroup difference was found $(P=.26)$ in the proportion of patients with pleurodesis: 12 of $54(22.2 \%)$ in the RT group versus 5 of $11(45.4 \%)$ in the LT group. Dietary restrictions such as institution of total parenteral nutrition, or a low-fat diet, were routinely imposed for all patients during the immediate postoperative period.

\section{Statistical Analysis}

Categoric variables are presented as frequencies or percentages, and the intergroup difference of the variables of interest was analyzed using Fisher's exact test. Continuous variables are expressed as medians with ranges, and the intergroup difference of the variables of interest was analyzed using the Wilcoxon rank-sum test or the Mann-Whitney $U$ test, as appropriate. To identify the risk factors that require left periaortic mass ligation, the logistic regression model was fitted. All reported $P$ values were 2 -sided. For statistical analysis, SPSS, version 12 (SPSS, Inc, Chicago, Ill) was used.

\section{RESULTS}

The clinical courses of all patients with TDML $(\mathrm{n}=70)$ are summarized in Figure 1. Five patients died before their chest tubes were successfully removed (5of 70; 7.1\%: 3 died after RT; and 2 died after the LT that came after RT). The causes of death included sepsis $(n=2)$, capillary leak syndrome $(\mathrm{n}=2)$, and low cardiac output $(\mathrm{n}=1)$. After excluding these 5 patients, data from 65 patients were used for analysis. Chylothoraces were successfully resolved after RT in 54 patients (RT group), whereas primary or secondary LT was required in 11 patients (LT group). The demographic data of these 65 patients are presented in Table 1. The median age and median weight at the time of the initial cardiac surgery was 172 days (range: 0 days- 62 months) and $6 \mathrm{~kg}$ (range: $1.5-15.3 \mathrm{~kg}$ ), respectively.

The laboratory diagnosis of chylothorax was confirmed at 9 days (range: 2-110 days) after the initial operation, and the first TDML was performed after a median duration of 13 days (range: 0-64 days) after the laboratory diagnosis of chylothorax with a maximal drainage of $42 \mathrm{~mL} / \mathrm{kg} /$ day (range: $7-232 \mathrm{~mL} / \mathrm{kg} /$ day). A gradual decrease in drainage occurred after primary or secondary TDML, and the chest tubes were removed, usually within 15 days (range: 2-79 days) after the first TDML, when the pleural drainage became $<2$ to $3 \mathrm{cc} / \mathrm{kg} / \mathrm{day}$. With respect to the initial cardiac operations, the number of patients who underwent an arterial switch operation was higher in the LT group ( $45.4 \%$ in the LT group vs $7.4 \%$ in the RT group; $P=.01$ ).

The clinical characteristics of the patients who underwent primary or secondary left periaortic mass ligation are summarized in Table 2. Three patients underwent primary TDML through LT for persistent left chylothrax: one was a premature baby $\left(23^{+4}\right.$ weeks' of gestation; birth weight of $570 \mathrm{~g}$ ) with an atrial septal defect who had delayed chylous effusion in the left side 4 months after the closure of the atrial septal defect; the other 2 patients had complex congenital heart defects and dextrocardia. Determination to use primary TDML through LT was based on pleural effusion being on the left side, the presence of dextrocardia, and individual surgeon preference.

Eight patients underwent secondary left periaortic mass ligation after the right-sided approach, at a median of 7 


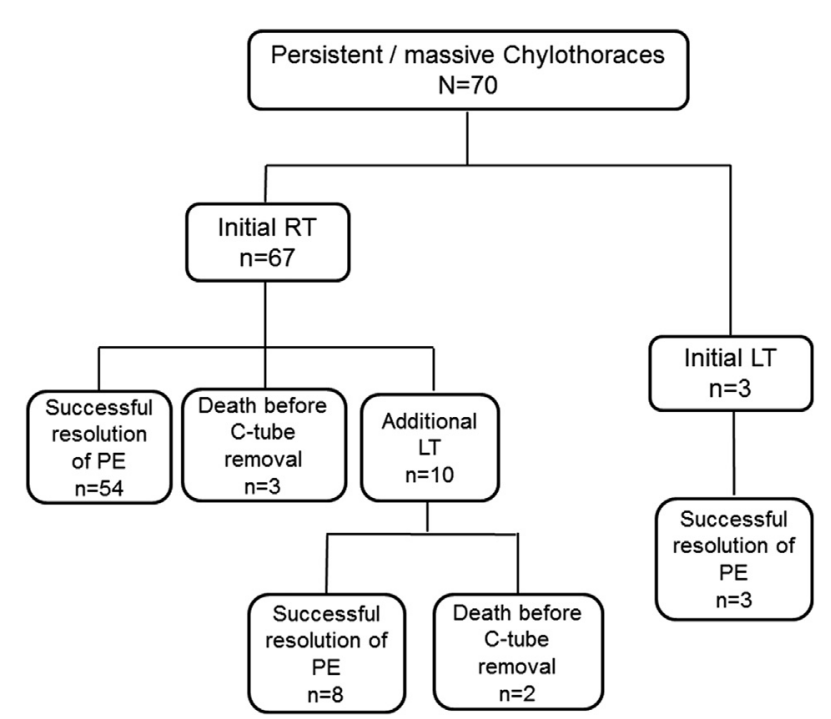

FIGURE 1. Outcome of thoracic duct mass ligation for postoperative chylothoraces in 70 patients. $R T$, Right thoracotomy; $P E$, pleural effusion; $C$-tube, chest-tube; $L T$, left thoracotomy.

days later (range: 2-19 days), with a maximum drainage of $112 \mathrm{~mL} / \mathrm{kg} /$ day (range: $18-232 \mathrm{~mL} / \mathrm{kg} /$ day) after right TDML. Patients in the LT group were more likely to have left-sided or both-sided pleural effusion $(81.8 \%$ vs $38.9 \%$; $P=.02$ ) (Figure 2), and the amount of pleural drainage before and after the initial TDML was significantly larger in the LT group ( $82 \pm 63$ vs $32 \pm 26 \mathrm{cc} / \mathrm{kg} / \mathrm{day} ; P=.02)$.
Table 3 compares the anatomic variables according to the side of the TDML. According to the cardiac morphology, patients in the LT group were more likely to have dextrocardia $(27.3 \%$ vs $5.6 \% ; P=.05)$. Logistic regression analysis showed that those in the LT group were more likely to have dextrocardia (odds ratio 6.38; 95\% confidence interval: 1.09 to $37.25 ; P=.04)$. The incidence of abnormal atrial situs, right descending thoracic aorta, great arterial malposition, and bilateral superior vena cava were comparable between the 2 groups (Table 4 ).

\section{DISCUSSION}

Regardless of the improvement in cardiac anesthesia, surgical techniques, and postoperative care over the past few decades, the incidence of chylothorax has not decreased. ${ }^{6}$ This lack of improvement may be attributable to the increasing number of complicated neonatal cardiac surgeries, ${ }^{3,11}$ and to single-ventricle palliation. ${ }^{3,6,16}$ In our study, the incidence of chylothorax and TDML was $3.3 \%$ and $0.7 \%$, respectively. This result was comparable to the incidence of postsurgical chylothorax in a contemporary series $(3.8 \%-6.6 \%)^{5,6,17,18}$

Various alternative measures have been suggested for chylothorax that is refractory to medical treatment, such as surgical ligation of cysterna chili, ${ }^{7}$ percutaneous thoracic duct embolization, ${ }^{8,19,20}$ and application with fibrin glue and argon beam coagulation on the presumed chyle

TABLE 1. Baseline characteristics of patients who underwent thoracic duct ligation

\begin{tabular}{|c|c|c|c|c|}
\hline Variable & Total $(n=65)$ & RT group $(n=54)$ & LT group $(n=11)$ & $P$ value \\
\hline Gender, male (n [\%]) & $45(69)$ & $38(70)$ & $7(64)$ & .73 \\
\hline Age at operation (d) & $172(0-1856)$ & $199(0-1856)$ & $12(0-351)$ & .33 \\
\hline Body weight at operation (kg) & $6(1.5-15.3)$ & $6(1.5-15.3)$ & $3(2.4-8.5)$ & .02 \\
\hline Interval, operation to Dx (d) & $9(2-110)$ & $9(2-23)$ & $9(3-110)$ & .83 \\
\hline Pre-TDML maximum drainage $(\mathrm{mL} / \mathrm{kg} / \mathrm{d})$ & $42(7-232)$ & $32(7-165)$ & $87(21-232)$ & .40 \\
\hline Interval, operation to TDML (d) & $23(7-120)$ & $26(7-87)$ & $20(8-120)$ & .07 \\
\hline Interval, Dx to TDML (d) & $13(0-64)$ & $16(0-64)$ & $10(5-14)$ & .04 \\
\hline \multicolumn{5}{|l|}{ Biochemical nature of pleural effusion } \\
\hline Cholesterol (mg/dL) & $47(12-198)$ & $47(12-198)$ & $33(12-71)$ & .13 \\
\hline Triglyceride (mg/dL) & $223(102-7130)$ & $212(102-7130)$ & $226(106-639)$ & .54 \\
\hline \multicolumn{5}{|l|}{ Types of initial operation } \\
\hline Fontan & $8(12.3)$ & $8(14.8)$ & $0(0.0)$ & .33 \\
\hline BCS & $12(18.5)$ & $11(20.4)$ & $1(9.1)$ & .67 \\
\hline TOF total correction & $9(13.8)$ & $9(16.7)$ & $0(0.0)$ & .34 \\
\hline Arterial switch & $9(13.8)$ & $4(7.4)$ & $5(45.4)$ & .02 \\
\hline TAPVR repair & $7(10.8)$ & $6(11.1)$ & $1(9.1)$ & .66 \\
\hline Aortic arch repair & $5(7.7)$ & $4(7.4)$ & $1(9.1)$ & .27 \\
\hline Rastelli & $3(4.6)$ & $3(5.6)$ & $0(0.0)$ & .57 \\
\hline One-and-a-half-ventricle repair & $3(4.6)$ & $2(3.7)$ & $1(9.1)$ & .43 \\
\hline Other & $9(13.8)$ & $7(13.0)$ & $2(18.1)$ & .22 \\
\hline Pleurodesis upon TDML & $17(26.1)$ & $12(22.2)$ & $5(45.4)$ & .26 \\
\hline CPB time (min) & $117(21-446)$ & $113(21-446)$ & $140(60-301)$ & .19 \\
\hline ACC time (min) & $51(0-174)$ & $51(0-145)$ & $73(0-174)$ & .07 \\
\hline
\end{tabular}

Values are median (range), unless otherwise indicated. Operation refers to initial cardiac operation. $R T$, Right thoracotomy; $L T$, left thoracotomy; $D x$, diagnosis; $T D M L$, thoracic duct mass ligation; $B C S$, bidirectional cavopulmonary shunt; TOF, tetralogy of Fallot; TAPVR, total anomalous pulmonary venous return; $C P B$, cardiopulmonary bypass; $A C C$, aortic crossclamp. 
TABLE 2. Characteristics of 11 patients who underwent left periaortic mass ligation

\begin{tabular}{|c|c|c|c|c|c|c|c|c|}
\hline & $\begin{array}{c}\text { Age/body } \\
\text { weight (kg) }\end{array}$ & Diagnosis & Initial operation & $\begin{array}{c}\text { Interval, } \\
\text { operation } \\
\text { to TDML (d) }\end{array}$ & $\begin{array}{c}\text { Pre-1st } \\
\text { TDML, } \\
\text { side of PE }\end{array}$ & $\begin{array}{l}\text { Interval, } \\
\text { 1st to 2nd } \\
\text { TDML (d) }\end{array}$ & $\begin{array}{c}\text { 1st-2nd } \\
\text { TDML, } \\
\text { side of PE }\end{array}$ & $\begin{array}{c}\text { Successful } \\
\text { resolution } \\
\text { of PE } \\
\end{array}$ \\
\hline \multicolumn{9}{|c|}{ Primary left periaortic mass ligation } \\
\hline 1 & $5 \mathrm{mo} / 2.9$ & $2^{\circ} \mathrm{ASD}$, prematurity & ASD closure & 110 & Left & NA & NA & Yes \\
\hline 2 & $13 \mathrm{~d} / 3.6$ & TGA with VSD, situs inversus totalis & ASO, VSD closure & 3 & Left & NA & NA & Yes \\
\hline 3 & $7 \mathrm{~d} / 3.1$ & FSV (c-AVSD, ccTGA, MA) & AVVP & 11 & Left & NA & NA & Yes \\
\hline \multicolumn{9}{|c|}{ Additional left periaortic mass ligation after TDML through RT } \\
\hline 4 & $12 \mathrm{mo} / 8.5$ & PA with VSD & One-and-a-half repair & 23 & Bilateral & 19 & Bilateral & Yes \\
\hline 5 & $10 \mathrm{mo} / 8$ & FSV (DORV, MA, PS) & BCS & 20 & Bilateral & 15 & Bilateral & Yes \\
\hline 6 & $12 \mathrm{~d} / 2.4$ & CoA with VSD & Anterior total repair & 20 & Bilateral & 3 & Left & Yes \\
\hline 7 & $9 \mathrm{~d} / 2.5$ & T-B anomaly, arch hypoplasia & Anterior total repair & 16 & Left & 4 & Left & Yes \\
\hline 8 & $14 \mathrm{~d} / 2.5$ & dTGA with VSD & ASO, VSD closure & 14 & Bilateral & 7 & Bilateral & Yes \\
\hline 9 & $10 \mathrm{~d} / 3.2$ & dTGA with VSD & ASO, VSD closure & 11 & Bilateral & 7 & Bilateral & Yes \\
\hline 10 & $0 \mathrm{~d} / 2.8$ & Infracardiac TAPVR & TAPVR repair & 21 & Right & 2 & Left & Yes \\
\hline 11 & $9 \mathrm{~d} / 3.4$ & dTGA with VSD & ASO, VSD closure & 14 & Left & 2 & Left & Yes \\
\hline
\end{tabular}

leakage site. ${ }^{9,21}$ The standard treatment has been TDML via RT. ${ }^{6,22}$ However, clinical studies regarding the management of standard treatment failure have been rare. In clinical practice, the standard approach for postsurgical chylothorax in patients with congenital heart disease has been known to result in significant treatment failure and death. ${ }^{6,10,22}$ Given that persistent chylothorax may lead to serious complications, including nutritional impairment, multi-organ dysfunction, and sepsis, further aggressive treatment is mandatory if chylous effusion persists after TDML via RT. ${ }^{1,2}$

The incidence of variations in the thoracic duct anatomy has been reported to be relatively high, even among healthy populations. ${ }^{13,15,22-25}$ Therefore, standard treatment failure in patients with congenital cardiac anomalies may well be attributable to the anatomic variations in the path of the thoracic duct. ${ }^{13}$ Congenital anomalies of the thoracic duct are caused by a developmental impediment within the first 8 or 9 weeks of embryonic life. ${ }^{18,24}$ Because embryonic development of the lymphatic system coincides with that of the cardiovascular system, ${ }^{26}$ anatomic variations of the thoracic duct tend to co-occur with cardiovascular anomalies, ${ }^{15}$ such as persistent left superior vena cava, ${ }^{13}$ aberrant right subclavian artery, ${ }^{14,16}$ and right-sided aortic arch.

Most reports pertaining to abnormal anatomy of the thoracic duct are based on postmortem findings, ${ }^{13,15,23,24}$ because in vivo diagnostic methods of visualizing the thoracic duct, such as lymphangiography ${ }^{19}$ or lymphoscintigraphy, ${ }^{27}$ are difficult to use, especially in pediatric patients. $^{22}$ Therefore, the current study examined the assumption that resolution of chylothorax after left periaortic mass ligation signifies an anatomic variation of the path of the thoracic duct, even though this premise might seem too speculative without concrete morphologic evidence. However, successful resolution of chylothorax after TDML through RT can at least be said to indicate a normal anatomic path of the thoracic duct.

In our study, dextrocardia was identified as the only morphologic parameter that indicates the need for left periaortic mass ligation. However, this does not necessarily mean that the primary, left-side approach is recommended for patients with dextrocardia. Rather, what we have inferred from this study is that TDML via RT is the standard treatment for all patients who have complex congenital heart defects, as suggested by others. ${ }^{3,4}$ If this strategy is unsuccessful, however, prompt application of an additional left-side approach is strongly recommended, because an abnormal thoracic duct path is frequently encountered in this subset of patients.

\section{Limitations}

This study is a retrospective review of a relatively small number of patients from a single center. Therefore, we failed to elucidate a direct relationship between the need for left periaortic mass ligation and various cardiac anomalies, such as abnormal atrial situs, abnormal great arterial relationships, aberrant left subclavian artery, bilateral superior vena cava, and right aortic arch. Only dextrocardia remained as a risk factor. This study is based on the premise that resolution of chylothorax after left periaortic mass ligation signifies an anatomic variation in the path of the thoracic duct, although this conclusion might seem too speculative.

Further, whether the resolution of chylothorax by LT after RT signifies either contralateral location of the thoracic duct (ie, a left periaortic course at the aortic hiatus) or bilateral 

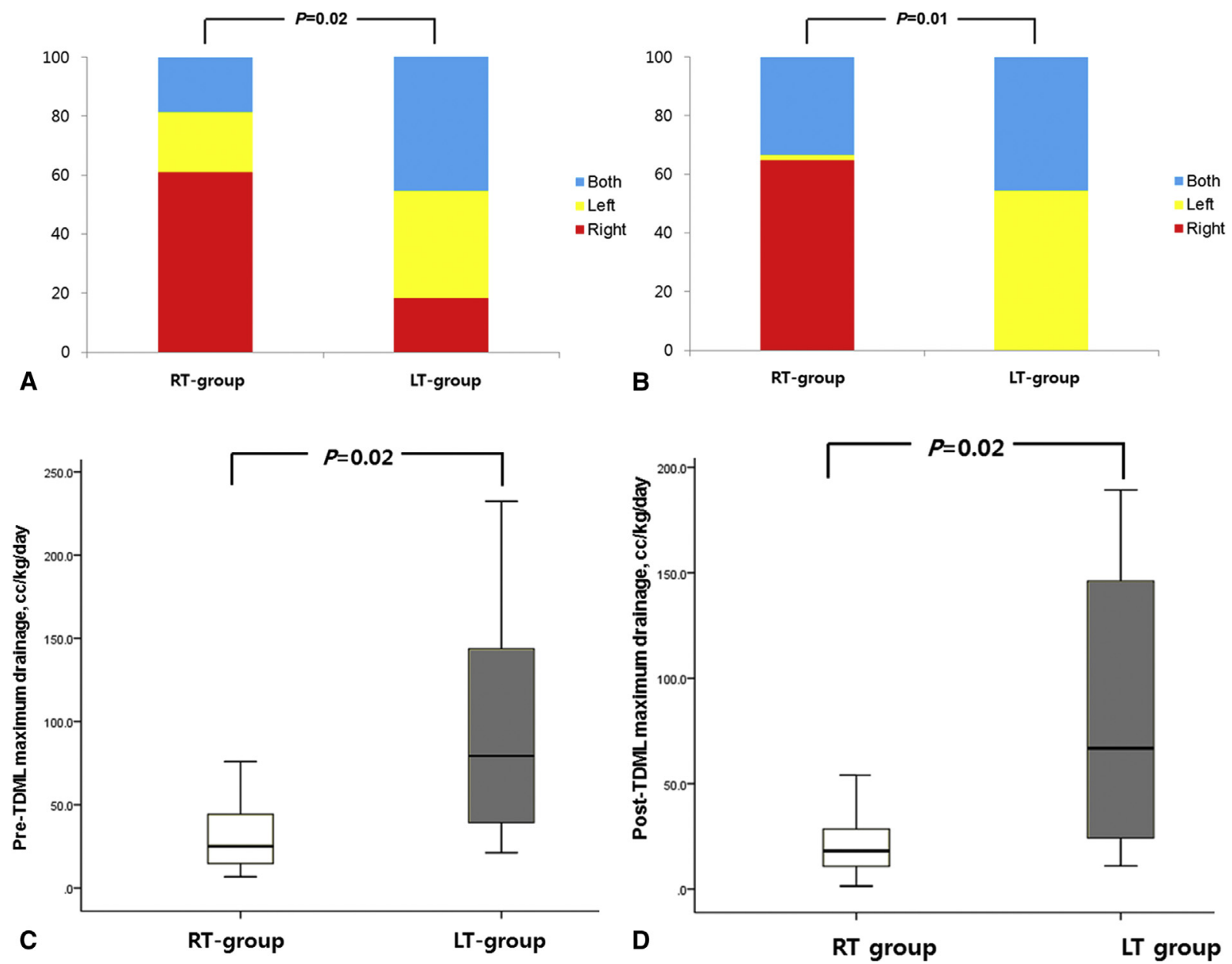

FIGURE 2. Pleural effusion sidedness and drainage according to group. A, Pre-TDML side of the pleural effusion. B, Post-TDML side of the pleural effusion. C, Pre-TDML drainage of the pleural effusion. D, Post-TDML drainage of the pleural effusion. RT, Right thoracotomy; $L T$, left thoracotomy; TDML, thoracic duct mass ligation.

TABLE 3. Anatomic characteristics according to group

\begin{tabular}{lcccc}
\hline \multicolumn{1}{c}{ Variable } & $\begin{array}{c}\text { Total } \\
(\mathbf{n = 6 5 )}\end{array}$ & $\begin{array}{c}\text { RT group } \\
(\mathbf{n}=\mathbf{5 4})\end{array}$ & $\begin{array}{c}\text { LT group } \\
(\mathbf{n}=\mathbf{1 1})\end{array}$ & $\boldsymbol{P}$ value \\
\hline Atrial situs & & & & .23 \\
$\quad$ Solitus & $58(89.2)$ & $49(90.7)$ & $9(81.8)$ & \\
$\quad$ Right isomerism & $3(4.6)$ & $3(3.7)$ & $0(0.0)$ & \\
$\quad$ Left isomerism & $3(4.6)$ & $2(3.7)$ & $1(9.1)$ & \\
$\quad$ Inversus & $1(1.5)$ & $0(0.0)$ & $1(9.1)$ & \\
Dextrocardia & $6(9.2)$ & $3(5.6)$ & $3(27.3)$ & .05 \\
Bilateral SVC & $10(15.4)$ & $7(13.0)$ & $3(27.3)$ & .22 \\
Great arteries relationship & & & & .08 \\
$\quad$ Normal & $42(64.6)$ & $38(70.4)$ & $4(36.4)$ & \\
$\quad$ d-TGA & $9(13.8)$ & $5(9.3)$ & $4(36.4)$ & \\
1-TGA & $5(7.7)$ & $4(7.4)$ & $1(9.1)$ & \\
$\quad$ Side-by-side & $9(13.8)$ & $7(13.0)$ & $2(18.2)$ & \\
Right descending aorta & $7(10.8)$ & $5(9.3)$ & $2(18.2)$ & .34 \\
Aberrant RSCA & $4(6.2)$ & $3(5.6)$ & $1(9.1)$ & .53 \\
Criss-cross heart & $2(3.1)$ & $2(3.7)$ & $0(0.0)$ & .99 \\
\hline Var
\end{tabular}

Values are $\mathrm{n}(\%) . R T$, Right thoracotomy; $L T$, left thoracotomy; $S V C$, superior vena cava; $d-T G A$, dextro transposition of the great arteries; l-TGA, 1 malposition of the aorta; $R S C A$, right subclavian artery. thoracic ducts, is unclear. We excluded from the analysis 5 patients who died after TDML with chest tube(s) in situ. Whether these patients would have been in the RT or LT group had they survived is unclear. These deaths may have had an impact on the outcome of the analysis.

TABLE 4. Univariate and multivariable risk-factor analyses for the left-sided approach

\begin{tabular}{|c|c|c|c|c|c|c|}
\hline \multirow[b]{2}{*}{ Variables } & \multicolumn{3}{|c|}{ Univariate analysis } & \multicolumn{3}{|c|}{ Multivariate analysis } \\
\hline & OR & $95 \% \mathrm{CI}$ & $\begin{array}{c}P \\
\text { value }\end{array}$ & OR & $95 \% \mathrm{CI}$ & $\begin{array}{c}P \\
\text { value }\end{array}$ \\
\hline Abnormal atrial situs & 2.18 & $0.37-13.00$ & .39 & & & \\
\hline GA malposition & 3.81 & $0.98-14.78$ & .05 & & & \\
\hline Dextrocardia & 6.38 & $1.09-37.25$ & .04 & 6.38 & $1.09-37.25$ & .04 \\
\hline BSVC & 2.52 & $0.53-11.82$ & .24 & & & \\
\hline CPB time & 1.004 & $0.99-1.01$ & .25 & & & \\
\hline OP body weight & 0.88 & $0.73-1.07$ & .21 & & & \\
\hline OP age & 0.99 & $0.99-1.001$ & .21 & & & \\
\hline
\end{tabular}




\section{CONCLUSIONS}

The path of the thoracic duct may vary in pediatric patients who have complex congenital heart disease. Left periaortic mass ligation should be considered in chylothorax refractory to right-side TDML, especially in patients with dextrocardia.

\section{Conflict of Interest Statement}

Authors have nothing to disclose with regard to commercial support.

You can watch a Webcast of this AATS meeting presentation by going to: http://webcast.aats.org/2015/Video/ Wednesday/04-29-15_612_0907_Bang.mp4.

\section{References}

1. Mery CM, Moffett BS, Khan MS, Zhang W, Guzman-Pruneda FA, Fraser CD, et al, Incidence and treatment of chylothorax after cardiac surgery in children: analysis of a large multi-institution database. J Thorac Cardiovasc Surg. 2014;147:678-86.

2. Brown KL, Ridout DA, Goldman AP, Hoskote A, Penny DJ. Risk factors for long intensive care unit stay after cardiopulmonary bypass in children. Crit Care Med. 2003;31:28-33

3. Beghetti M, La Scala G, Belli D, Bugmann P, Kalangos A, Le Coultre C. Etiology and management of pediatric chylothorax. J Pediatr. 2000;136:653-8.

4. Nguyen DM, Shum-Tim D, Dobell ARC, Tchervenkov CI. The management of chylothorax/chylopericardium following pediatric cardiac surgery: a 10 year experience. J Card Surg. 1995;10:302-8.

5. Cannizzaro V, Frey B, Bernet-Buettiker V. The role of somatostatin in the treatment of persistent chylothorax in children. Eur J Cardiothorac Surg. 2006;30:49-53.

6. Chan EH, Russell JL, Williams WG, Van Arsdell GS, Coles JG, McCrindle BW. Postoperative chylothorax after cardiothoracic surgery in children. Ann Thorac Surg. 2005;80:1864-70.

7. Zanin A, Padalino MA, Cerutti A, Vida VL, Milanesi O, Stellin G, et al. Surgical ligation of cisterna chyli: an alternative treatment for chronic chylothorax in children. Ann Thorac Surg. 2010;90:1732-4.

8. Cope C. Management of chylothorax via percutaneous embolization. Curr Opin Pulm Med. 2004;10:311-4.

9. Stenzl W, Rigler B, Tscheliessnigg KH, Beitzke A. Treatment of postsurgical chylothorax with fibrin glue. Thorac Cardiovasc Surg. 1983;31:35-6.

10. Liu CS, Tsai HL, Chin TW, Wei CF. Surgical treatment of chylothorax caused by cardiothoracic surgery in children. J Chin Med Assoc. 2005;68:234-6.

11. Burke RP, Wernovsky G, van der Velde M, Hansen D, Castaneda AR. Video-assisted thoracoscopic surgery for congenital heart disease. J Thorac Cardiovasc Surg. 1995;109:499-508.

12. McGrath EE, Blades Z, Anderson PB. Chylothorax: aetiology, diagnosis and therapeutic options. Respir Med. 2010;104:1-8.

13. Chen H, Shoumura S, Emura S. Bilateral thoracic ducts with coexistent persistent left superior vena cava. Clin Anat. 2006;19:350-3.

14. Okumura K, Fujimoto T. A case of anomalous right subclavian artery passing behind the esophagus with a rare variation of the thoracic duct. Acta Anat Jpn. 1974;49:179-83.

15. Cha EM, Sirijintakarn P. Anatomic variation of the thoracic duct and visualization of mediastinal lymph nodes: a lymphographic study. Radiology. 1976;119:45-8.

16. Nathan H, Seidel MR. The association of a retroesophageal right subclavian artery, a right-sided terminating thoracic duct, and a left vertebral artery of aortic origin: anatomical and clinical considerations. Acta Anat. 1983;117:362-73.

17. Büttiker V, Fanconi S, Burger R. Chylothorax in children: guidelines for diagnosis and management. Chest. 1999;116:682-7.

18. Skandalakis JE, Skandalakis LJ, Skandalakis PN. Anatomy of the lymphatics. Surg Oncol Clin N Am. 2007;16:1-16.

19. Allison S, Rainey M, Aarabi S, Padia SA. Traumatic laceration of the cisterna chyli treated by lymphangiography and percutaneous embolization. Cardiovasc Intervent Radiol. 2014;37:267-70.

20. Itkin M, Kucharczuk JC, Kwak A, Trerotola SO, Kaiser LR. Nonoperative thoracic duct embolization for traumatic thoracic duct leak: experience in 109 patients. J Thorac Cardiovasc Surg. 2010;139:584-90.

21. Rifai N, Sfeir R, Rakza T, Alameh J, Besson R, Lequien P, et al. Successful management of severe chylothorax with argon plasma fulguration and fibrin glue in a premature infant. Eur J Pediatr Surg. 2003;13:324-6.
22. Soto-Martinez M, Massie J. Chylothorax: diagnosis and management in children. Paediatr Respir Rev. 2009;10:199-207.

23. Akcali O, KirayIpek A, Suleyman E, Alici TE. Thoracic duct variations may complicate the anterior spine procedures. Eur Spine J. 2006;15:1347-51.

24. Elliott GE, Thompson KL. A previously undocumented pre-aortic pathway of the thoracic duct: a case report. Int J Anat Var. 2013;6:221-4.

25. Phang K, Bowman M, Phillips A, Windsor J. Review of thoracic duct anatomical variations and clinical implications. Clin Anat. 2014;27:637-44.

26. Brotons ML, Bolca C, Fréchette É, Deslauriers J. Anatomy and physiology of the thoracic lymphatic system. Thorac Surg Clin. 2012;22:139-53.

27. Bourgeois P, Munck D, Sales F. Anomalies of thoracic lymph duct drainage demonstrated by lymphoscintigraphy and review of the literature about these anomalies. Eur J Surg Oncol. 2008;34:553-5.

Key Words: chylothorax, pleural effusion, thoracic duct, dextrocardia

\section{Discussion}

Dr H. Ichikawa (Osaka, Japan). Thank you for this opportunity; it is a privilege to discuss with you your excellent data. Thank you also for sending me your paper beforehand.

Chylothorax is one of the frequent and annoying complications that if severe and intractable enough, rarely but potentially leads to death. The authors analyzed their retrospective data and described the efficacy of left-sided TDML. They also analyzed the factors that necessitated left-sided TDML and concluded that the presence of dextrocardia is a factor, using multivariate analysis.

I have 4 questions.

The first question is about the incidence of chylothorax in your institution. For me, it seems to be a little bit on the high side in terms of the incidence that necessitates ligation. We often encounter a small, low-grade chylothorax, but we rarely need to perform ligation. So, do you know the standard incidence of chylothorax after congenital heart surgery? That is the first question.

Dr J.H. Bang (Seoul, Republic of Korea). Thank you for your comments, Dr Ichikawa. Despite the improvements in surgical techniques and postoperative care, the incidence of chylothorax has not decreased. This can be attributed to the increasing number of surgical candidates, many of whom are neonates and have complex congenital heart disease and lower birth weight. In the present study, the incidence of chylothorax was $3.3 \%$, and this result was comparable to those in several reports. A review from Sick Kids showed that the incidence of chylothorax was $3.8 \%$, and the prevalence of chylothorax was reported as $6.6 \%$ in Switzerland, $2.3 \%$ in China, and $4.7 \%$ in New Zealand.

Dr Ichikawa. The second question is also related to the incidence of chylothorax. In your institution, you, of course, evaluated which factors necessitated ligation. But in general, many instances of chylothorax usually can be treated medically. So what do you think are the factors that trigger chylothorax in your institution?

Dr Bang. Patients who required ductal ligation in our center were more likely to have single-ventricular 
palliations. Beghetti found that high pressure in the superior vena cava may result in chylothorax. The Fontan or Glenn procedure may influence the superior vena cava pressure, and this preceded a higher incidence of chylothorax. Another risk factor for chylothorax is superior vena cava thrombosis. We had 11 patients who had documented superior vena cava thrombosis.

Dr Ichikawa. The third question is about your left thoracotomy. In the patients who required left thoracotomy, do you think the preceding right thoracotomy was necessary, or do you think that left thoracotomy only should be indicated from the beginning?

Dr Bang. If you had evidence of an abnormal path of the thoracic duct, you might consider periaortic mass ligation. But in South Korea, lymphangiography, lymphoscintigraphy, or cardiac magnetic resonance imaging have not been widely used in pediatric patients. Another reason is that Cha and colleagues identified 65 variations in the path of the thoracic duct, in 243 cases. They demonstrate that up to $30 \%$ of patients had variations of the thoracic duct. Because of this incidence of variations of the thoracic duct, we suggest that in case of standard treatment failure, left periaortic mass ligation be considered.

Dr Ichikawa. My last and fourth question concerns the word "dextrocardia." It actually means many things. So, for the dextrocardia patients you had, is it actually apicocaval juxtaposition, or just that the apex is right sided?

Dr Bang. The word "dextrocardia" means that the heart is misplaced in the right side of the chest with the apex pointing right. In the present study, the term "dextrocardia" encompasses a wide spectrum, from mirror-image dextrocardia to dextroversion. Of course, it includes such patients with or without apicocaval juxtaposition.

Dr B. Alsoufi (Atlanta, Georgia). Very quick questions. First, do you propose performing lymphangiography before thoracic duct ligation to better plan the site of intervention?

Second, if you suspect iatrogenic injury to the thoracic duct after thoracotomy, such as in coarctation or vascular ring repair, do you think the timing or the site of intervention should change? For example, after vascular ring repair, do you think you should go earlier directly to the left side to try to ligate the injured duct rather than doing the mass ligation on the right side?

Dr Bang. Lymphoscintigraphy, lymphangiography, and cardiac magnetic resonance imaging have not been widely used in pediatric patients, so we demonstrate that if the standard treatment fails, left periaortic mass ligation may be considered.

Dr T.J. Yun (Seoul, Republic of Korea). Can I answer the question on her behalf?

Dr Cameron. Yes.

Dr Yun. Regarding the first question, here is a typical clinical scenario: a 3-kg baby has had an arterial switch operation, is on a ventilator and cachectic, and is actually dying of massive chylothorax. Because it is very difficult to perform a lymphangiogram or magnetic resonance imaging in this baby, to directly diagnose the course of the thoracic duct, we might have to do additional treatment as a trial. I have to admit that this is an assumption-based treatment, rather than an evidence-based treatment. But this is a kind of rescue procedure to try anything we can do to stop the leak.

Regarding the second question, if you perform a left thoracotomy and you somehow injure the thoracic duct, you may have to try every option, such as primary closure of the leaking point, or whatever. If the leak does not stop after several days, then you have to think about the TDML from the right side. With respect to the initial operation, all the patients in our series were approached anteriorly. Therefore, direct injury of the thoracic duct could not be the cause of the chylothorax. 